Article

\title{
Solubility, Solution Thermodynamics, and Preferential Solvation of Amygdalin in Ethanol + Water Solvent Mixtures
}

\author{
Abdelkarim Aydi 1,2,*, Cherifa Ayadi ${ }^{3,4}$, Kaouther Ghachem ${ }^{5}$, Abdulaal Z. Al-Khazaal ${ }^{6}$, \\ Daniel R. Delgado ${ }^{7}$ (D), Mohammad Alnaief ${ }^{8}$ and Lioua Kolsi ${ }^{9,10}$ (D)
}

1 LETIAM, Lip (Sys)2, IUT d'Orsay, Université Paris-Sud, Plateau de Moulon, 91400 Orsay, France

2 Laboratory of Materials Molecules and Applications, Preparatory Institute for Scientific and Technical Studies, University of Carthage, Tunis 1082, Tunisia

3 Laboratory of Materials, Treatment and Analysis (LMTA), National Institute of Research and Physicochemical Analysis (INRAP), BiotechPole Sidi-Thabet, Ariana 2020, Tunisia; sherifa.ayadi@gmail.com

4 Faculté des Sciences de Tunis, Université Tunis El Manar, Campus Universitaire El Manar, Tunis 2092, Tunisia

5 Department of Industrial Engineering and Systems, College of Engineering, Princess Nourah bint Abdulrahman University, Riyadh 84428, Saudi Arabia; kgmaatki@pnu.edu.sa

6 Department of Chemical and Materials Engineering, Faculty of Engineering, Northern Border University, Arar P.O. Box 1321, Saudi Arabia; abdulaal.alkhazaal@gmail.com

7 GRIAUCC Research Group, Department of Engineering, Industrial Engineering Program, Universidad Cooperativa de Colombia, Calle 11 No. 1-51, Neiva 410001, Huila, Colombia; danielr.delgado@campusucc.edu.co

8 Department of Pharmaceutical and Chemical Engineering, Faculty of Applied Medical Sciences, German Jordanian University, Amman 11180, Jordan; mohammad.alnaief@gju.edu.jo

9 Department of Mechanical Engineering, College of Engineering, Ha'il University,

Ha'il City 81481, Saudi Arabia; 1.kolsi@uoh.edu.sa

10 Laboratory of Metrology and Energy Systems, National Engineering School of Monastir, University of Monastir, Monastir 5000, Tunisia

* Correspondence: aydiabdelkarim@gmail.com; Tel.: +004-91-52-3775-0478

Received: 14 October 2020; Accepted: 12 November 2020; Published: 16 November 2020

\begin{abstract}
The equilibrium solubility of amygdalin in [ethanol (1) + water (2)] mixtures at $293.15 \mathrm{~K}$ to $328.15 \mathrm{~K}$ was reported. The thermodynamic properties (standard enthalpy $\Delta_{\text {soln }} \mathrm{H}^{\circ}$, standard entropy $\Delta_{\text {soln }} S^{\circ}$, and standard Gibbs energy of solution $\Delta_{\text {soln }} G^{\circ}$ ) were computed using the generated solubility data via van't Hoff and Gibbs equations. The dissolution process of amygdalin is endothermic and the driving mechanism in all mixtures is entropy. Maximal solubility was achieved in 0.4 mole fraction of ethanol at $328.15 \mathrm{~K}$ and the minimal one in neat ethanol at $293.15 \mathrm{~K}$. Van't Hoff, Jouyban-Acree-van't Hoff, and Buchowski-Ksiazczak models were used to simulate the obtained solubility data. The calculated solubilities deviate reasonably from experimental data. Preferential solvation parameters of amygdalin in mixture solvents were analyzed using the inverse Kirkwood-Buff integrals (IKBI) method. Amygdalin is preferentially solvated by water in ethanol-rich mixtures, whereas in water-rich mixtures, there is no clear evidence that determines which of water or ethanol solvents would be most likely to solvate the molecule.
\end{abstract}

Keywords: amygdalin; thermodynamics; van't Hoff; Gibbs equation; solubility; Jouyban-Acree; Buchowski-Ksiazczak; inverse Kirkwood-Buff integral 


\section{Introduction}

Amygdalin (Figure 1) is a naturally occurring cyanogenic diglycoside with a molecular formula of $\mathrm{C}_{20} \mathrm{H}_{27} \mathrm{NO}_{11}$ and a molecular mass of $457.4 \mathrm{~g} \mathrm{~mol}^{-1}$. It is a major bioactive component present mostly in kernels and seeds of "Rosaceae" plants such as peaches, apples, cherries, and more [1,2]. The use of amygdalin can lead to the release of toxic hydrogen cyanide (HCN) through the action of emulsin enzyme from the human intestinal microflora [3]. The HCN selectively decomposes cancer cells in the tumor site inside the body [4,5]. Several studies have demonstrated the antitumor activities of amygdalin on prostate cancer, bladder cancer, lung cancer, rectal cancer, and colon cancer [6]. Furthermore, highly purified amygdalin used in therapeutic dosage levels has antioxidant, anti-fibrosis [7], anti-inflammatory, analgesic [8,9], anti-atherosclerosis [10-12], anti-cardiac hypertrophy [13], anti-ulcer [14], anti-tussive, and anti-asthmatic effects [15].<smiles>N#CC(OC1OC(COC2OC(CO)C(O)C(O)C2O)C(O)C(O)C1O)c1ccccc1</smiles>

Figure 1. Molecular structure of amygdalin.

Besides the degradation of amygdalin caused by enzymes from the gut microflora, plant enzymes ( $\beta$-glucosidases and $\alpha$-hydroxynitrile lyases) can lead to the production of cyanide when plant tissue is damaged or seeds are crushed or macerated. Enzymatic degradation of amygdalin to gentibiose, benzaldehyde, and HCN usually takes place in an alkaline solution [16].

In addition to enzymatic hydrolysis mentioned above, amygdalin degradation can also occur in boiling water through the process of epimerization, particularly under mild basic conditions as well as in a long extraction time [17-19]. In Bolarinwa et al.'s research [17], it was demonstrated that at $100{ }^{\circ} \mathrm{C}$ of boiling water, an extended extraction period can result in reduced extraction yield due to the conversion of amygdalin into neoamygdalin (amygdalin epimer).

Extracting a high rate of amygdalin from food plants without causing degradation of the molecule is challenging to achieve. Therefore, the selectivity of a solvent for this compound is a crucial parameter, as this will have a paramount influence on the extraction process. Extraction rate and time can be considerably affected by amygdalin solubility in solvents [17]. It is therefore of some interest to know the solubility of amygdalin in different mixtures of solvents. On the other hand, the knowledge of the solubility behavior in different solvent systems is of high importance in the pharmaceutical industry as it influences the drug efficacy and its pharmacokinetics [20]. Solubility data are also useful for drug purification, refining procedures, and method development [21-23].

For the above-mentioned reasons, the solubility and solution thermodynamics of amygdalin in pure and solvent mixtures are quite essential and must be determined. The binary water and ethanol mixtures are the most versatile and most used solvent systems for these previous purposes [24-27].

Thus, the goals of this study were (1) to extend the database on the solubility of amygdalin in several ethanol (1) + water (2) mixtures over a temperature range of 298.105 to $328.15 \mathrm{~K}$, (2) to study the effect of solvent composition on the solubility and solution thermodynamics of amygdalin in aqueous ethanol mixtures, (3) to calculate the apparent thermodynamic functions of solution in the investigated 
solvents using the van't Hoff and Gibbs equations, and (4) to estimate the preferential solvation of amygdalin in these solvents through the method of inverse Kirkwood-Buff integrals (IKBI), which describes the local solvent proportions around the dissolved substance concerning to the composition of the cosolvent mixtures [28,29]. Some models were used to predict the solubility of amygdalin in ethanol-water mixtures at different temperatures.

\section{Results and Discussion}

\subsection{Solubility of Amygdalin in [Ethanol (1) + Water (2)] Cosolvent Mixtures}

Table 1 shows the experimental solubility of amygdalin (3) in \{ethanol (1) + water (2)\} cosolvent mixtures including EtOH and water neat solvents at nine temperatures (293.15-328.15 K).

Table 1. Experimental solubility of amygdalin (3) expressed in molar fraction $\left(10^{3} \mathrm{x}_{3}{ }^{\mathrm{a}}\right)$ in [ethanol (1) + water (2)] mixtures at different temperatures. Experimental pressure p: $0.1 \mathrm{MPa}{ }^{b}$.

\begin{tabular}{cccccccccc}
\hline \multirow{2}{*}{$\boldsymbol{x}_{\mathbf{1}}{ }^{\mathbf{c}, \mathbf{d}}$} & \multicolumn{8}{c}{ Temperature/K } \\
\cline { 2 - 10 } & $\mathbf{2 9 3 . 1 5}$ & $\mathbf{2 9 8 . 1 5}$ & $\mathbf{3 0 3 . 1 5}$ & $\mathbf{3 0 8 . 1 5}$ & $\mathbf{3 1 0 . 1 5}$ & $\mathbf{3 1 3 . 1 5}$ & $\mathbf{3 1 8 . 1 5}$ & $\mathbf{3 2 3 . 1 5}$ & $\mathbf{3 2 8 . 1 5}$ \\
\hline 0.00 & 2.54 & 3.25 & 4.19 & 5.49 & 6.07 & 7.04 & 7.91 & 9.73 & 11.0 \\
\hline 0.10 & 2.80 & 3.55 & 4.61 & 6.16 & 6.69 & 7.83 & 8.86 & 10.8 & 12.9 \\
\hline 0.20 & 3.07 & 3.99 & 5.21 & 7.12 & 7.42 & 8.84 & 10.4 & 12.2 & 14.6 \\
\hline 0.30 & 3.34 & 4.48 & 5.84 & 8.08 & 8.32 & 9.90 & 11.8 & 13.6 & 16.9 \\
\hline 0.40 & 3.56 & 5.06 & 6.60 & 8.39 & 9.32 & 11.0 & 13.3 & 15.3 & 18.3 \\
\hline 0.50 & 3.12 & 4.06 & 4.84 & 5.90 & 5.99 & 7.26 & 8.67 & 9.52 & 12.1 \\
\hline 0.60 & 2.20 & 2.58 & 3.17 & 3.94 & 4.14 & 4.81 & 5.55 & 6.30 & 7.89 \\
\hline 0.70 & 1.53 & 1.88 & 2.14 & 2.52 & 2.83 & 3.25 & 3.77 & 4.12 & 5.45 \\
\hline 0.80 & 1.00 & 1.21 & 1.36 & 1.70 & 1.76 & 2.02 & 2.44 & 2.62 & 2.93 \\
\hline 0.90 & 0.71 & 0.83 & 0.91 & 1.12 & 1.15 & 1.27 & 1.35 & 1.57 & 1.70 \\
\hline 1.00 & 0.51 & 0.56 & 0.61 & 0.65 & 0.69 & 0.77 & 0.91 & 0.94 & 1.03 \\
\hline
\end{tabular}

a Average relative uncertainty in mole fraction solubility is $\mathrm{u}\left(\mathrm{x}_{3}\right)=0.025$. ${ }^{\mathrm{b}}$ Standard uncertainty in pressure $\mathrm{u}(\mathrm{p})=0.001 \mathrm{MPa} .{ }^{\mathrm{c}} x_{1}$ is the mole fraction of ethanol (1) in the ethanol (1) + water (2) $\}$ mixtures free of amygdalin (3). $\mathrm{d}$ Average relative standard uncertainty in $x_{1}$ is $\operatorname{ur}\left(\mathrm{x}_{1}\right)=0.01 .{ }^{\mathrm{e}} \mathrm{T}$ is the absolute temperature. Standard uncertainty in temperature is $u(T)=0.05 \mathrm{~K}$.

Experimental results demonstrate that the solubility increases with temperature indicating endothermic dissolution (Figure 2A). The maximum solubility of amygdalin was observed in the cosolvent mixture $x_{1}=0.4$ at $328.15 \mathrm{~K}$ (Figure 2B). The addition of ethanol (in water-rich mixtures) has a positive cosolvent effect, enhancing amygdalin solubility. Indeed, the presence of the non-polar phenyl group in the amygdalin chemical structure may cause the formation of a structured water layer around it. As the proportion of ethanol in the solvent mixture increases, the solvation water shell will be ruptured [30-32], therefore, increasing amygdalin's solubility in the system.

The solubility profiles of amygdalin in \{ethanol (1) + water (2)\} binary mixtures at different temperatures were plotted as a function of the Hildebrand solubility parameter $\delta_{1+2}$ of the mixtures (Figure 2C). 

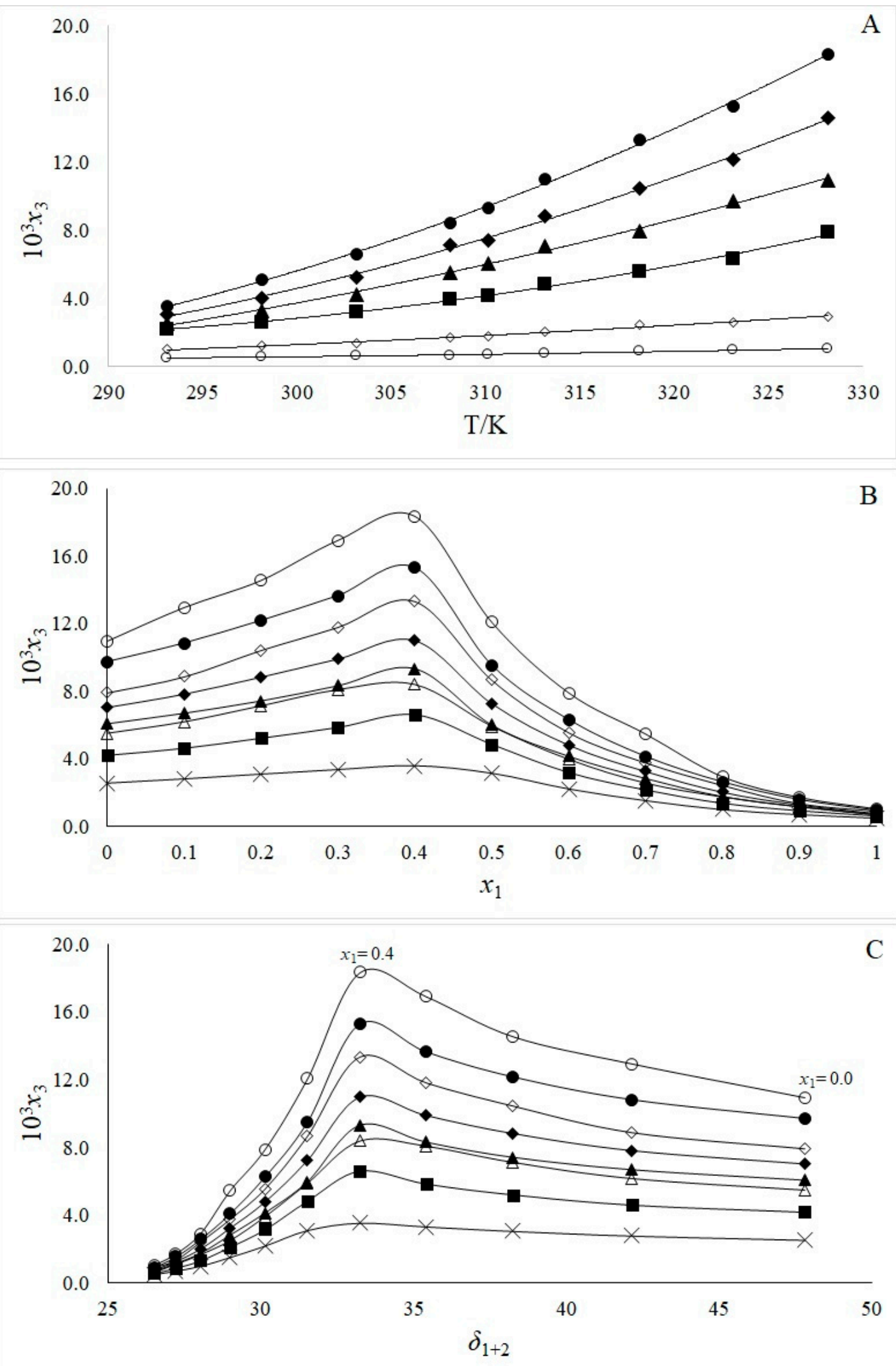

Figure 2. Experimental solubility of amygdalin (3) in mole fraction $\left(10^{3} \mathrm{x}_{3}\right)$ as a function of temperature (A); as a function of composition of solvent mixtures (B); and as a function of Hildebrand solubility parameter $\delta_{1+2}$ of the [ethanol (1) + water (2)] mixtures (C). For A, $\bigcirc$ : EtOH; $\diamond: x_{1}=0.8 ; \mathbf{n}: \mathbf{x}_{1}=0.6$;

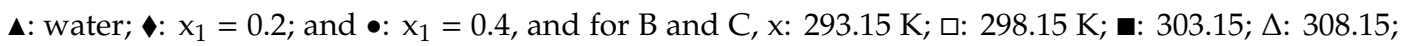
$\Delta: 310.15 \mathrm{~K} ; \bullet: 313.15 \mathrm{~K} ; \diamond: 318.15 \mathrm{~K} ; \bullet: 323.15 \mathrm{~K}$; and $\bigcirc: 328.15 \mathrm{~K}$. 
For binary mixtures, $\delta_{1+2}$ is calculated as [33]:

$$
\delta_{1+2}=f_{1} \delta_{1}+\left(1-f_{1}\right) \delta_{2}
$$

where $\delta_{1}$ and $\delta_{2}$ are the Hildebrand solubility parameters of the pure solvents $\left(\delta_{1}=26.5 \mathrm{MPa}^{1 / 2}\right.$ for ethanol (1) [34] and $\delta_{2}=47.8 \mathrm{MPa}^{1 / 2}$ for water (2) [34]; $f$ is the solute-free volume fraction which is calculated assuming additive volumes as:

$$
f=V_{1} /\left(V_{1}+V_{2}\right)
$$

where $V_{1}$ and $V_{2}$ are the volumes of cosolvent and water, respectively.

Considering the entire polarity region, the solubility increases from pure water $\left(\delta=47.8 \mathrm{MPa}^{1 / 2}\right)$ up to the mixture with $\mathrm{x}_{1}=0.40\left(\delta_{\text {mix }}=33.2 \mathrm{MPa}^{1 / 2}\right)$, where the curve shows a maximum solubility peak; from this mixture up to pure ethanol, the solubility decreases in all cases (Figure 2C).

This behavior is commonly observed in compounds whose polarity coincides with the polarity of a mixture of solvents $\left(\delta_{1}>\delta_{3}>\delta_{2}\right.$ or $\left.\delta_{2}>\delta_{3}>\delta_{1}\right)[35,36]$.

According to the literature, solutes reach their maximum solubility in solvents with the same solubility parameter [36] and thus, the $\delta_{3}$ value of amygdalin (3) would be $33.2 \mathrm{MPa}^{1 / 2}$. However, the solubility parameter of amygdalin (3), estimated in accordance with the group contribution methods proposed by Fedors and van Krevelen, is $\delta_{3}=29.9 \mathrm{MPa}^{1 / 2}$ (Table 2), which is lower than the experimental value obtained in this work at the solubility maximum $\left(\delta_{3}=33.2 \mathrm{MPa}^{1 / 2}\right)$.

\begin{tabular}{|c|c|c|c|}
\hline Group or Atom & Quantity & $\Delta \mathrm{V}\left(\mathrm{cm}^{3} \mathrm{~mol}^{-1}\right)$ & $\Delta \mathrm{U}\left(\mathrm{kJ} \mathrm{mol}^{-1}\right)$ \\
\hline$-\mathrm{CH}_{2}$ & 2 & 16.1 & 4.94 \\
\hline$-\mathrm{CH}<$ & 11 & 13.5 & 4.31 \\
\hline$-\mathrm{OH}$ & 7 & 10 & 29.8 \\
\hline$-\mathrm{O}-$ & 4 & 3.8 & 3.35 \\
\hline$-\mathrm{C} \equiv \mathrm{N}$ & 1 & 24 & 25.5 \\
\hline Phenyl & 1 & 71.4 & 31.9 \\
\hline Ring closure & 1 & 16 & 1.05 \\
\hline \multicolumn{2}{|c|}{ Total } & 377.3 & 337.74 \\
\hline & & & $\delta_{3}=(337,740 / 377.3)^{1 / 2}=29.9 \mathrm{MPa}^{1 / 2}$ \\
\hline
\end{tabular}

Table 2. Estimation of the solubility parameter of amygdalin by Fedor's method [34].

It is important to note that the group contribution methods only provide a rough estimation of $\delta_{3}$; however, this calculation is relevant to identify the most suitable solvent or solvent mixture to dissolve the drug, which is useful information in experimental and industrial designs.

\subsection{Computational Validation}

The use of calculation models to predict the solubility of chemicals in mixed solvents is one of the lines of research that have evolved the most in recent years. Some of the most widely implemented models are those of, van't Hoff, Jouyban-Acree-van't Hoff and Buchowski-Ksiazczak $\lambda$ h.

Thus, the van't Hoff equation (Equation (3)) presents a relationship between solubility (expressedin mole fraction) and temperature.

$$
x_{3}=e^{\left(A+\frac{B}{T}\right)}
$$

$A$ and $B$ are parameters, which can be related to thermodynamic parameters such as dissolution enthalpy and dissolution entropy [37]. 
Jouyban and Acree developed a specific model for the prediction of the solubility of drugs in \{ethanol (1) + water (2)\} cosolvent mixtures at a specific temperature (Equation (4)) [38-40]:

$$
\ln x_{3,1+2}=x_{1} \ln x_{3,1}+x_{2} \ln x_{3,2}+x_{1} x_{2}\left[724.21 T^{-1}+485.17\left(x_{1}-x_{2}\right) T^{-1}+194.41\left(x_{1}-x_{2}\right)^{2} T^{-1}\right]
$$

Introducing the van't Hoff model, the Jouyban-Acree would be left, with the advantage of being able to calculate solubility at various temperatures [41].

$$
\begin{gathered}
\ln x_{3,1+2}=x_{1}\left(\mathrm{~A}_{1}+\mathrm{B}_{1} T^{-1}\right)+x_{2}\left(\mathrm{~A}_{2}+\mathrm{B}_{2} T^{-1}\right)+ \\
x_{1} x_{2}\left[724.21 T^{-1}+485.17\left(x_{1}-x_{2}\right) T^{-1}+194.41\left(x_{1}-x_{2}\right)^{2} T^{-1}\right]
\end{gathered}
$$

For this investigation, when calculating A and B coefficients by linear regression, the following equation is obtained:

$$
\begin{gathered}
\ln x_{3,1+2}=x_{1}\left(-0.69 \pm 0.22-2048 T^{-1}\right)+x_{2}\left(8.06 \pm 0.28-4101 \pm 87 T^{-1}\right) \\
+x_{1} x_{2}\left[724.21 T^{-1}+485.17\left(x_{1}-x_{2}\right) T^{-1}+194.41\left(x_{1}-x_{2}\right)^{2} T^{-1}\right]
\end{gathered}
$$

The Buchowski-Ksiazczak $\lambda h$ equation, (Equation (8)), is another way to describe the solubility behavior:

$$
x_{3}=\frac{\lambda e^{\lambda h T_{f}^{-1}}}{\lambda e^{\lambda h T_{f}^{-1}}-e^{\lambda h T_{f}^{-1}}+e^{\lambda h T^{-1}}}
$$

where $\lambda$ and $h$ are the two parameters of the Buchowski-Ksiazczak model, and $T_{f}$ represents the melting point of drug [42-44].

The mean percentage deviation (MPD) was calculated from Equation (8) [45,46]:

$$
\mathrm{MPD}=\frac{100}{N} \sum \frac{\left|\mathrm{x}_{3,1+2}^{\mathrm{cal}}-\mathrm{x}_{3,1+2}^{\operatorname{Exp}}\right|}{\mathrm{x}_{3,1+2}^{\operatorname{Exp}}}
$$

where $N$ is the number of experimental data points, and $x_{3,1+2}^{\text {cal }}$ and $x_{3,1+2}^{\operatorname{Exp}}$ are the calculated and experimental solubility values.

Thus, amygdalin solubility was estimated employing Equations (3), (6), and (7) and then, the MPD values were calculated using Equation (8).

The MDP values show that the model that best predicts the experimental data is the van't Hoff model (3.3\%), followed by the Buchowski-Ksiazczak model (4.3\%), and finally, the Jouyban-Acree-van't Hoff mode presents a MDP of $22.8 \%$.

Figure 3 shows the calculated solubility versus observed solubility data of amygdalin in \{ethanol (1) + water (2)\} cosolvent mixtures, using the van't Hoff, Jouyban-Acree-van't Hoff and Buchowski-Ksiazczak models. A relatively low determination coefficient was observed $\left(R^{2}=0.76\right)$ indicating a poor prediction accuracy for the Jouyban-Acree-van't Hoff model; however, the van't Hoff and Buchowski-Ksiazczak models present correlation coefficients close to one, indicating a good correlation of the data calculated with these models and the experimental data.

Therefore, in general terms, the Jouyban-Acree-van't Hoff model does not predict the solubility of amygdalin in \{ethanol (1) + water (2)\} cosolvent mixtures adequately; however, the van't Hoff and Buchowski-Ksiazczak models show very good precision, as demonstrated with the MDP values. 


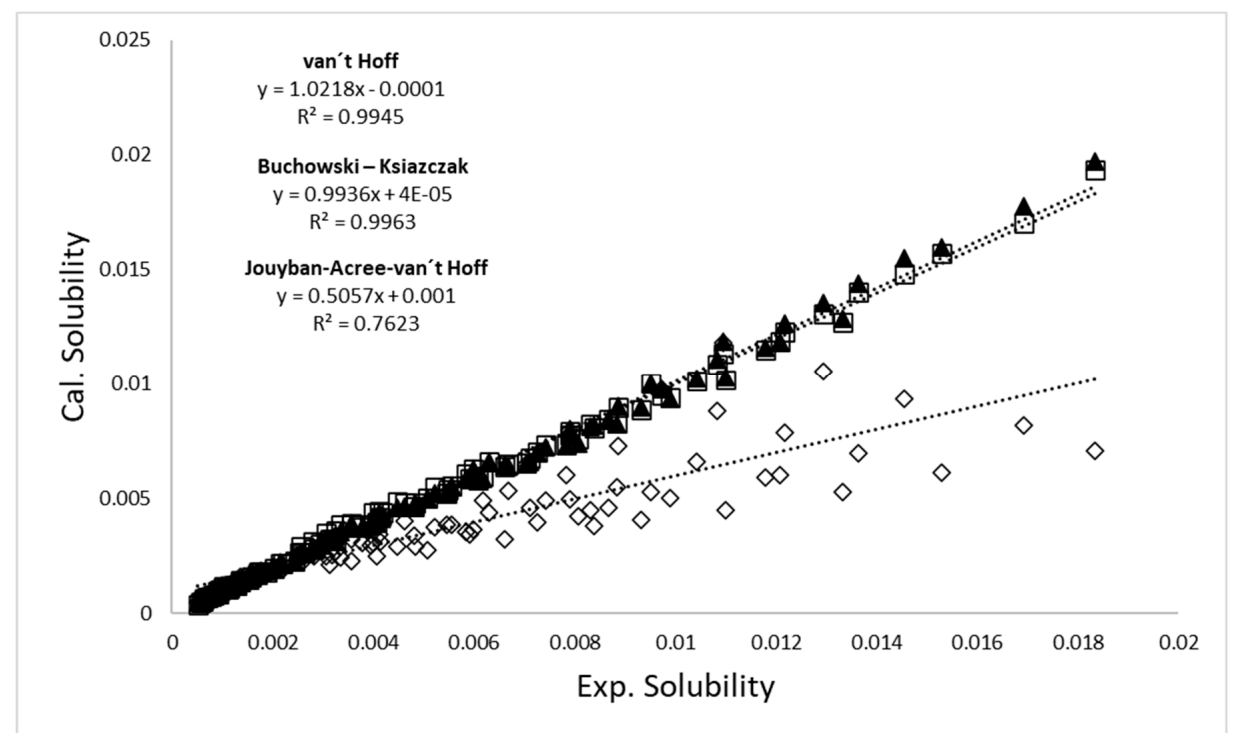

Figure 3. Plot of calculated versus experimental solubility data of amygdalin in \{ethanol (1) + water (2)\} cosolvent mixtures ( $\Delta=$ van't Hoff, $\square=$ Buchowski-Ksiazczak, and $\diamond=$ Jouyban-Acree-van't Hoff).

\subsection{Thermodynamic Functions of Dissolution}

From the experimental solubility data (Table 1), the thermodynamic functions of dissolution (Table 3) were calculated using the van't Hoff and Gibbs equations, under Krug modifications [47,48]:

$$
\begin{gathered}
\Delta_{\text {soln }} H^{o}=-R\left(\partial \ln x_{3} / \partial\left(T^{-1}-T_{\mathrm{hm}}^{-1}\right)\right) \\
\Delta_{\text {soln }} G^{o}=-R \times T_{\mathrm{hm}} \times \text { intercept } \\
\Delta_{\text {soln }} S^{o}=\left(\Delta_{\text {soln }} H^{o}-\Delta_{\text {soln }} G^{o}\right) T_{\mathrm{hm}}^{-1}
\end{gathered}
$$

where $\Delta_{\text {soln }} H^{o}$ represents the solution standard enthalpy, $\Delta_{\text {soln }} S^{o}$ represents the solution standard entropy, $\Delta_{\text {soln }} G^{o}$ represents the solution standard Gibbs energy, $R$ represents the constant of gases, and $T_{\mathrm{hm}}$ represents the mean harmonic temperature defined as: $T_{\mathrm{hm}}=n / \Sigma(1 / T)$, where $n$ is the number of studied temperatures (the harmonic mean temperature for this investigation is $310.22 \mathrm{~K}$ ).

\begin{tabular}{|c|c|c|c|c|c|c|}
\hline$x_{1}{ }^{\mathrm{a}}$ & $\begin{array}{r}\Delta_{\text {soln }} G^{o} / \\
\mathrm{kJ} \mathrm{mol}^{-1}\end{array}$ & $\begin{array}{l}\Delta_{\text {soln }} H^{o} / \\
\mathrm{kJ} \mathrm{mol}^{-1}\end{array}$ & $\begin{array}{c}\Delta_{\text {soln }} S^{\circ} / \\
\mathrm{J} \mathrm{mol}^{-1} \mathrm{~K}^{-1}\end{array}$ & 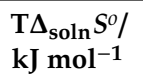 & $\zeta_{H}{ }^{b}$ & $\zeta_{\mathrm{TS}} \mathbf{b}$ \\
\hline 0.00 & 13.31 & 34.10 & 67.03 & 20.79 & 0.621 & 0.379 \\
\hline 0.10 & 13.02 & 35.34 & 71.93 & 22.31 & 0.613 & 0.387 \\
\hline 0.20 & 12.71 & 35.86 & 74.62 & 23.15 & 0.608 & 0.392 \\
\hline 0.30 & 12.41 & 36.77 & 78.52 & 24.36 & 0.601 & 0.399 \\
\hline 0.40 & 12.15 & 37.04 & 80.21 & 24.88 & 0.598 & 0.402 \\
\hline 0.50 & 13.07 & 29.92 & 54.31 & 16.85 & 0.640 & 0.360 \\
\hline 0.60 & 14.13 & 29.10 & 48.26 & 14.97 & 0.660 & 0.340 \\
\hline 0.70 & 15.12 & 28.14 & 41.95 & 13.01 & 0.684 & 0.316 \\
\hline 0.80 & 16.32 & 25.36 & 29.14 & 9.04 & 0.737 & 0.263 \\
\hline
\end{tabular}

Table 3. Thermodynamic functions of dissolution processes of amygdalin in $\{$ ethanol (1) + water (2) \} cosolvent mixtures at $T_{\mathrm{hm}}=310.22 \mathrm{~K}$. 
Table 3. Cont.

\begin{tabular}{|c|c|c|c|c|c|c|}
\hline$x_{1}{ }^{\mathrm{a}}$ & $\begin{array}{r}\Delta_{\text {soln }} G^{o} / \\
\mathrm{kJ} \mathrm{mol}^{-1}\end{array}$ & $\begin{array}{r}\Delta_{\text {soln }} H^{o} / \\
\mathrm{kJ} \mathrm{mol}^{-1}\end{array}$ & $\begin{array}{c}\Delta_{\text {soln }} S^{o} / \\
\mathrm{J} \mathrm{mol}^{-1} \mathrm{~K}^{-1}\end{array}$ & $\begin{array}{l}\mathrm{T} \Delta_{\text {soln }} S^{o} / \\
\mathrm{kJ} \mathrm{mol} \mathrm{mol}^{-1}\end{array}$ & $\zeta_{\mathbf{H}} \mathbf{b}$ & $\zeta_{\mathrm{TS}} \mathbf{b}$ \\
\hline 0.90 & 17.48 & 20.26 & 8.96 & 2.78 & 0.879 & 0.121 \\
\hline 1.00 & 18.66 & 17.03 & -5.25 & -1.63 & 0.913 & 0.087 \\
\hline
\end{tabular}

a $x_{1}$ is the mole fraction of ethanol (1) in the \{ethanol (1) + water (2)\} mixtures free of amygdalin (3). Standard uncertainty in $T$ is $u(T)=0.10 \mathrm{~K}$. Average relative standard uncertainties in apparent thermodynamic quantities of real dissolution processes are $u_{\mathrm{r}}\left(\Delta_{\text {soln }} G^{o}\right)=0.02, u_{\mathrm{r}}\left(\Delta_{\text {soln }} H^{o}\right)=0.02, u_{\mathrm{r}}\left(\Delta_{\text {soln }} S^{o}\right)=0.03$, and $u_{\mathrm{r}}\left(T \Delta_{\text {soln }} S^{o}\right)=0.03 .{ }^{\mathrm{b}} \zeta_{H}$ and $\zeta_{T S}$ are the relative contributions by enthalpy and entropy toward apparent Gibbs energy of dissolution.

Upon graphing $\ln \mathrm{x}_{3}$ vs. $\left(T^{-1}-T_{\mathrm{hm}}{ }^{-1}\right)$, the slope $\left(\partial \ln \mathrm{x}_{3} / \partial\left(T^{-1}-T_{\mathrm{hm}}{ }^{-1}\right)\right)$ and intercept used in Equations (10) and (11) are obtained.

Table 3 shows the data for the apparent thermodynamic functions of solution for amygdalin, $\Delta_{\text {soln }} H^{o}, \Delta_{\text {soln }} G^{o}$, and $\Delta_{\text {soln }} S^{o}$. The values of the slope and intercept with their respective standard deviations were calculated using the TableCurve 2D program. The resulting graphs are linear for each of the $\mathrm{EtOH}+\mathrm{W}$ cosolvent mixtures, obtaining correlation coefficients very close to 1 for first order linear regressions $(y=a+b x)$ (Figure 4).

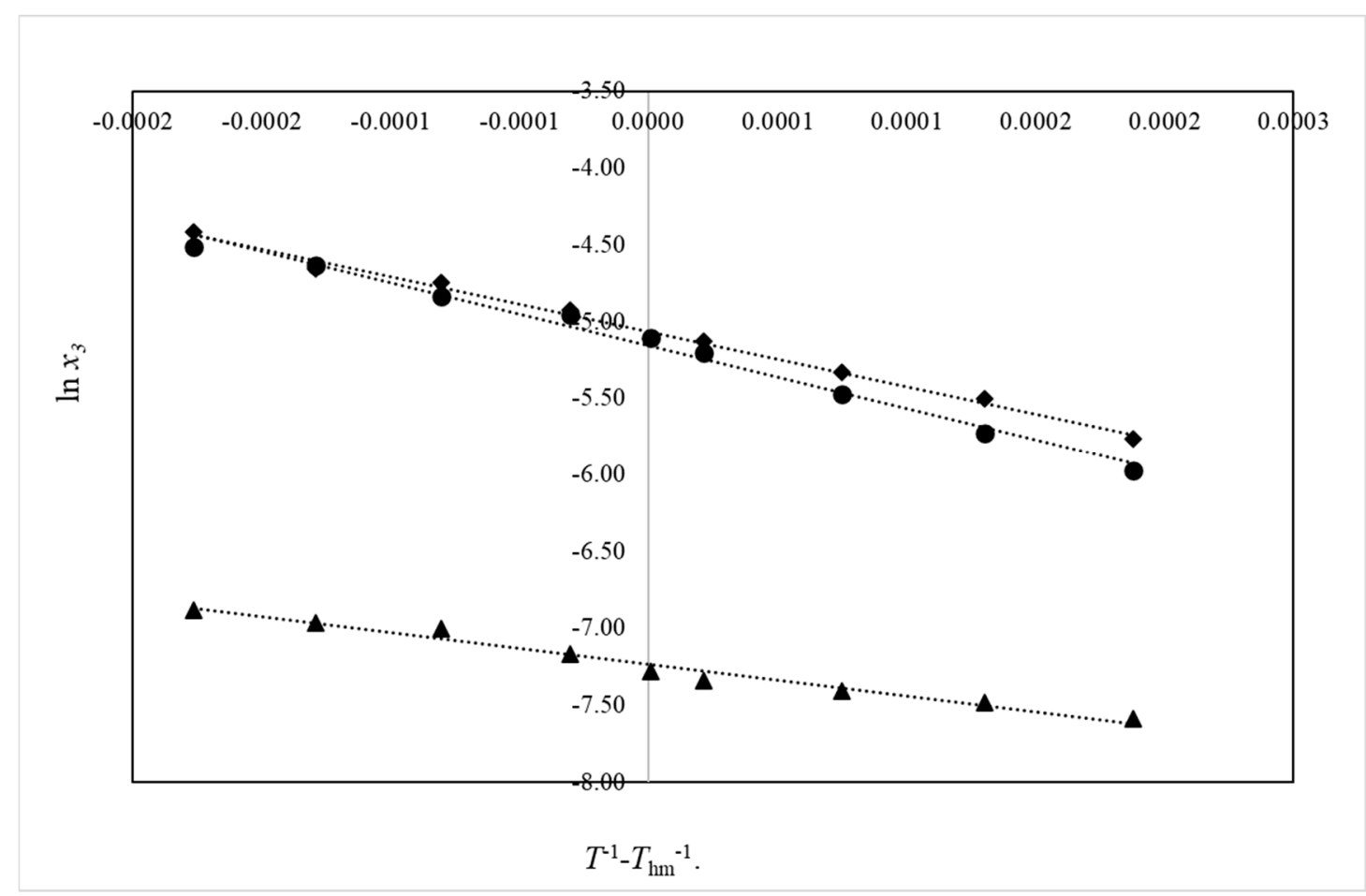

Figure 4. The van't Hoff plots for amygdalin in $\{$ ethanol $(1)+$ water $(2)\}$ cosolvent mixtures $\left(\bullet: x_{1}=0.0\right.$; $\checkmark: \mathrm{x}_{1}=0.5$; and $\left.\mathbf{\Lambda}: \mathrm{x}_{1}=1.0\right)$.

The standard Gibbs energy $\Delta_{\text {soln }} G^{o}$ (Table 3) is positive over the whole composition range and decreases from neat water to the cosolvent mixture $x_{1}=0.4$. From this solvent composition to pure $\mathrm{EtOH}, \Delta_{\text {soln }} G^{o}$ increases. The $\Delta_{\text {soln }} H^{o}$ is positive in every case indicating that the process of dissolution of amygdalin powder in solvents is endothermic $[49,50]$. The enthalpic values increase nonlinearly from neat water up to $40 \%$ in volume of $\mathrm{EtOH}$, presumably because, by increasing ethanol content, the interaction of this solvent with the solute promotes the breaking of the structured water molecules (hydrogen bonds) around the non-polar group of amygdalin [33,51]. As for the standard entropy of solution $\left(\Delta_{\mathrm{soln}} S^{o}\right)$, it is negative for pure ethanol, while it is positive for water-rich mixtures, suggesting an overall entropy-driven process for the latter mixtures. The relative contributions by 
enthalpy $\left(\zeta_{H}\right)$ and by entropy $\left(\zeta_{T S}\right)$ toward standard Gibbs free energy of solution are given by Equations (12) and (13), respectively:

$$
\begin{gathered}
\zeta_{H}=\left|\Delta_{\text {soln }} H^{o}\right|\left(\left|\Delta_{\text {soln }} H^{o}\right|+\left|T_{\mathrm{hm}} \Delta_{\text {soln }} S^{o}\right|\right)^{-1} \\
\zeta_{\text {TS }}=\left|T_{\mathrm{hm}} \Delta_{\text {soln }} S^{o}\right|\left(\left|\Delta_{\text {soln }} H^{o}\right|+\left|T_{\mathrm{hm}} \Delta_{\text {soln }} S^{o}\right|\right)^{-1}
\end{gathered}
$$

It may be seen from Table 4 that, in all cases, the main contributor to the (positive) standard Gibbs energy of dissolution is the (positive) enthalpy term $\left(\zeta_{H}>0.59\right)$.

Table 4. Coefficients of the Equation (22) to Gibbs energy of transfer of amygdalin (3) at several temperatures.

\begin{tabular}{cccccc}
\hline Coefficient & $\mathbf{2 9 3 . 1 5} \mathbf{K}$ & $\mathbf{2 9 8 . 1 5} \mathbf{K}$ & $\mathbf{3 0 3 . 1 5} \mathbf{K}$ & $\mathbf{3 0 8 . 1 5} \mathbf{K}$ & $\mathbf{3 1 3 . 1 5} \mathbf{K}$ \\
\hline$a$ & -0.0022 & 0.0356 & 0.0446 & 0.0879 & 0.0706 \\
\hline$b$ & -0.3574 & -1.2782 & 1.8586 & -5.1881 & -3.8227 \\
\hline$c$ & -20.48 & -19.625 & -18.477 & -1.9751 & -8.7567 \\
\hline$d$ & 53.775 & 55.874 & 57.349 & 32.26 & 43.505 \\
\hline$e$ & -29.053 & -30.735 & 32.277 & -19.838 & -25.332 \\
\hline$R^{2}$ & 0.998 & 0.994 & 0.995 & 0.993 & 0.994 \\
\hline
\end{tabular}

\subsection{Enthalpy-Entropy Compensation}

The study of enthalpy-entropy compensation effects for solute dissolution has been used to identify the main mechanism involved in the cosolvent behavior on dissolution processes $[52,53]$. Plots of $\Delta_{\text {soln }} H^{o}$ as a function of $\Delta_{\text {soln }} G^{o}$ or $\mathrm{T} \Delta_{\text {soln }} S^{o}$ at the harmonic temperature are employed for this purpose.

Thus, when plotting $\Delta_{\text {soln }} H^{o}$ vs. $\Delta_{\text {soln }} G^{o}$, a positive slope will indicate an enthalpy-driven dissolution process, while a negative one will indicate an entropy-driven dissolution process [39].

Similarly, when plotting $\Delta_{\text {soln }} H^{o}$ vs. $\mathrm{T} \Delta_{\text {soln }} S^{o}$, a slope greater than one will indicate an enthalpy-driven dissolution processes while a slope of less than one indicates entropy-driven dissolution processes [7,52-56].

Figure 5 shows that amygdalin in \{ethanol (1) + water (2)\} mixture solvents exhibits two trends, both with a negative slope, suggesting that the whole dissolution process is driven by entropy.

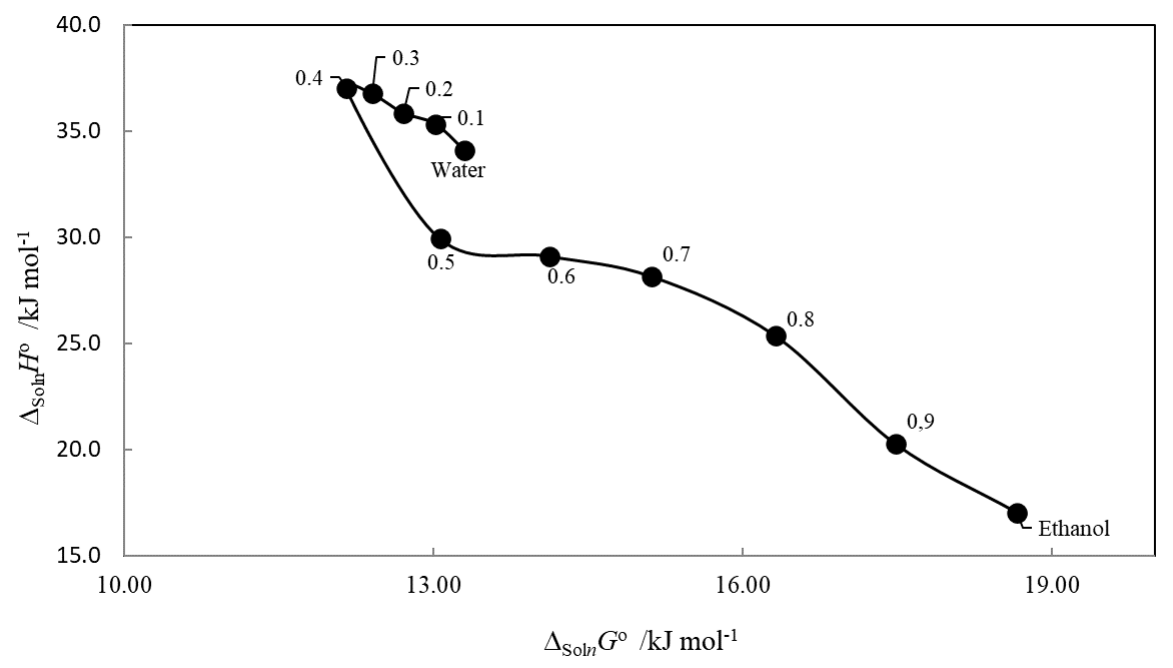

Figure 5. Enthalpy-entropy compensation graph of $\Delta_{\text {soln }} H^{o}$ vs. $\Delta_{\text {soln }} G^{o}$ at $T_{h m}=310.22 \mathrm{~K}$. 
When plotting $\Delta_{\text {soln }} H^{o}$ vs. $T \Delta_{\text {soln }} S^{o}$ (Figure 6), a linear trend is observed, described by the following equation: $\Delta_{\text {Soln }} H^{o}=0.758 \pm 0.014 T \Delta_{\text {Soln }} S^{o}+18.15 \pm 0.25$. The slope is inferior to 1 , which corroborates the previous results.

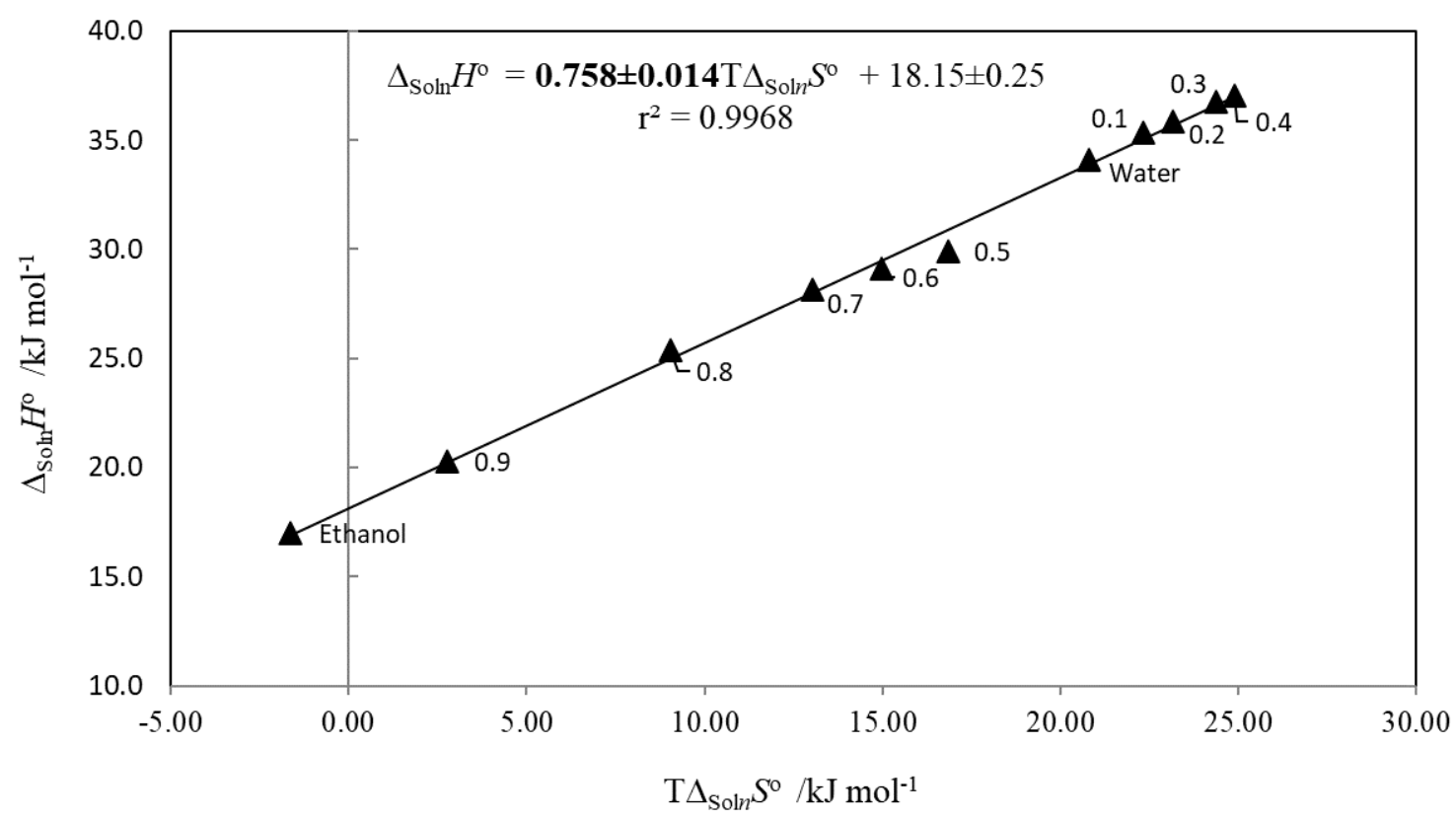

Figure 6. Enthalpy-entropy compensation graph of $\Delta_{\text {soln }} H^{o}$ vs. $\mathrm{T} \Delta_{\text {soln }} S^{o}$ at $T_{\mathrm{hm}}=310.22 \mathrm{~K}$.

\subsection{Preferential Solvation}

The preferential solvation model suggested by Ben Naim, called the inverse Kirkwood-Buff Integral (IKBI), allows determining, at the molecular level, the arrangement of the solvent molecules that make up the cosolvent mixture around a dissolved solute molecule [57-59].

This model allows to obtain the preferential solvation parameter of amygdalin (3) by ethanol molecules $\left(\delta x_{1,3}\right)$ according to [60-62]:

$$
\delta x_{1,3}=\left[x_{1}\left(1-x_{1}\right)\left(G_{1,3}-G_{2,3}\right)\right]\left[x_{1} G_{1,3}+\left(1-x_{1}\right) G_{2,3}+V_{c o r}\right]^{-1}
$$

where $x_{1}$ is the molar fraction of ethanol-free amygdalin, $G_{1,3}$ and $G_{2,3}$ are the Kirkwood-Buff integrals $\left(\mathrm{cm}^{3} \mathrm{~mol}^{-1}\right)$, and $V_{\text {cor }}$ is the correlation volume $\left(\mathrm{cm}^{3} \mathrm{~mol}^{-1}\right)$.

Thus, $G_{1,3}$ and $G_{2,3}$ are calculated as $[63,64]$ :

$$
\begin{gathered}
G_{1,3}=R T \kappa_{T}-V_{3}+\left(1-x_{1}\right) V_{2} D Q^{-1} \\
G_{2,3}=R T \kappa_{T}-V_{3}+x_{1} V_{1} D Q^{-1}
\end{gathered}
$$

where $\kappa_{T}$ is the isothermal compressibility of ethanol + water mixtures $\left(\mathrm{GPa}^{-1}\right), V_{1}$ and $V_{2}$ are the molar volumes of ethanol and water, respectively, in the mixtures $\left(\mathrm{cm}^{3} \mathrm{~mol}^{-1}\right)$, and $V_{3}$ is the molar volume of amygdalin in the mixed solvent $\left(\mathrm{cm}^{3} \mathrm{~mol}^{-1}\right)$

$V_{\text {cor }}$ is defined as $[65,66]$ :

$$
V_{\text {cor }}=2522.5\left[r_{3}+0.1363 \sqrt[3]{x_{1,3}^{L} V_{1}+x_{2,3}^{L} V_{2}}-0.085\right]^{3}
$$

where $x_{1,3}{ }^{L}$ is the local molar fraction of ethanol (1) in the surrounding area of amygdalin (3) and $r_{3}$ is the amygdalin molecular radius $(\mathrm{nm})$. 
$V_{c o r}$ is calculated by iteration using Equations (15) and (18) [67]:

$$
\delta x_{1,3}=x_{1,3}^{L}-x_{1}
$$

The functions $D$ and $Q\left(\mathrm{~kJ} \mathrm{~mol}^{-1}\right)$ are calculated using the following equations:

$$
\begin{aligned}
& Q=R T+x_{1} x_{2}\left(\frac{\partial^{2} G_{1,2}^{E}}{\partial x_{2}^{2}}\right)_{T, P} \\
& D=\left(\partial \Delta_{t r} G_{3,2 \rightarrow 1+2}^{o} / \partial x_{1}\right)_{T, P}
\end{aligned}
$$

$\Delta_{t r} G_{3,2 \rightarrow 1+2}^{o}$ is the standard molar Gibbs energy of transfer of the solute from pure water to each \{ethanol (1) + water (2)\} mixture and $G^{E}{ }_{1,2}$ is the excess molar Gibbs energy of mixing of the two solvents free of amygdalin.

Figure 7 shows the behavior of the Gibbs energy of transfer of amygdalin (3) from pure water (2) to \{ethanol (1) + water (2)\} mixtures at several temperatures. The numerical values were computed from the experimental solubility data (Table 1), by using the following equation:

$$
\begin{gathered}
\Delta_{t r} G_{3,2 \rightarrow 1+2}^{o}=R T \ln \left(x_{3,2} x_{3,1+2}^{-1}\right) \\
\Delta_{t r} G_{3,2 \rightarrow 1+2}^{o}=a+b x_{1}+c x_{1}{ }^{2}+d x_{1}{ }^{3}+e x_{1}{ }^{4}
\end{gathered}
$$

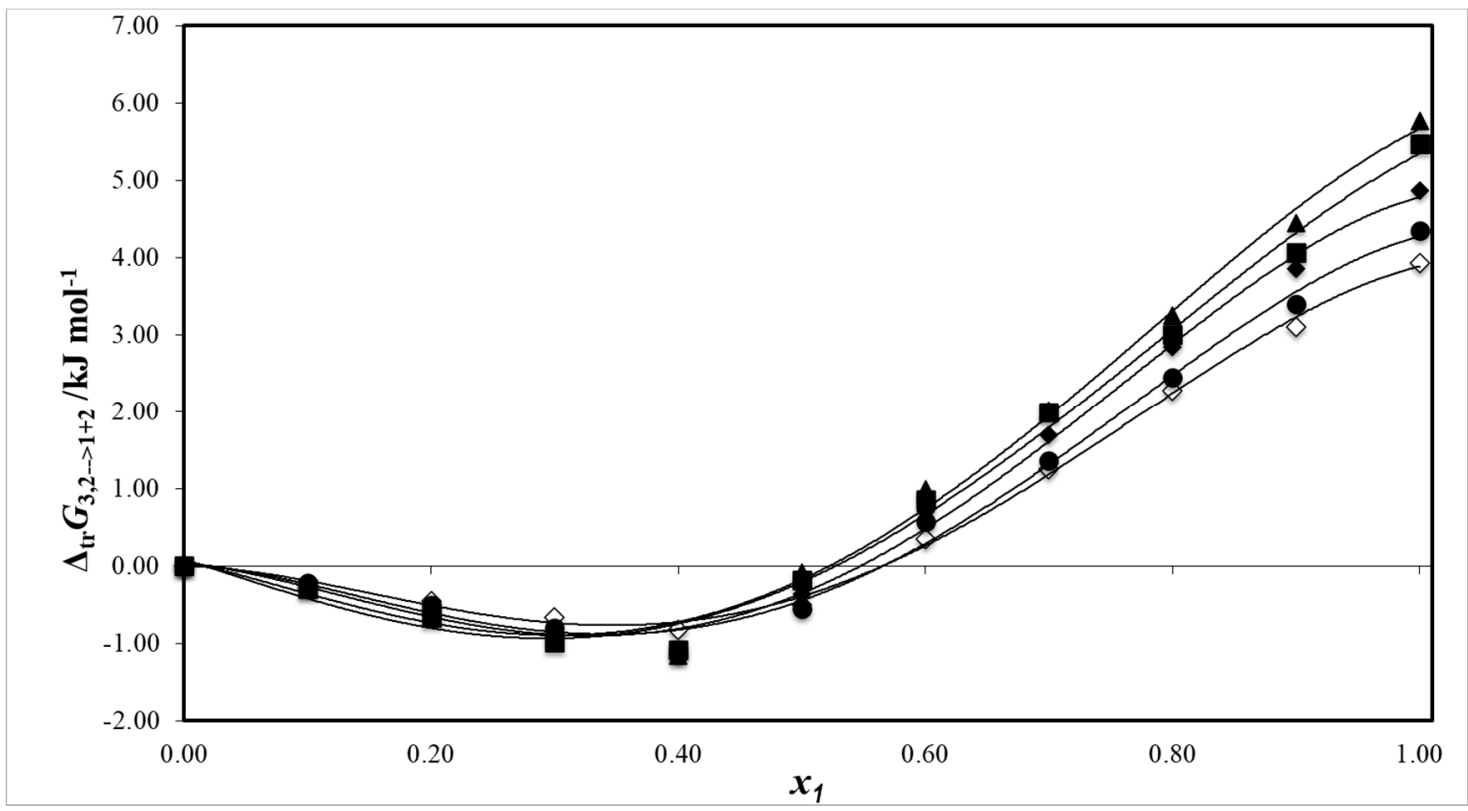

Figure 7. Gibbs energy of transfer of amygdalin (3) from pure water (2) to \{ethanol (1) + water (2)\} mixtures at several temperatures: $\square: 293.15 \mathrm{~K}$; $: 298.15 \mathrm{~K}$; : $303.15 \mathrm{~K}$; $\mathbf{\square}: 308.15 \mathrm{~K}$; and $\mathbf{\Delta}: 313.15 \mathrm{~K}$.

Table 4 records the numerical values of the coefficients of Equation (22) at 293.15, 298.15, 303.15, 308.15 , and $313.15 \mathrm{~K}$.

On the other hand, $Q$ is calculated according to Equation (19), where $G_{1.2}{ }^{\mathrm{E}}$ is calculated as [64]:

$$
G_{1,2}^{\mathrm{E}}=\mathrm{x}_{1} \mathrm{x}_{2}\left[2907-777\left(1-2 \mathrm{x}_{1}\right)+494\left(1-2 \mathrm{x}_{2}\right)^{2}\right]
$$

Once $\mathrm{D}$ and $\mathrm{Q}$ are calculated together with the isothermal compressibility $\left(\kappa_{\mathrm{T}}\right)$ for water $\left(0.457 \mathrm{GPa}^{-1}\right)\left[68\right.$ ] and ethanol $\left(1.248 \mathrm{GPa}^{-1}\right)$, in addition to the molar volumes of amygdalin and the solvents in the binary mixture reported by Jiménez et al. [69], the Kirkwood-Buff integrals are 
calculated, and from these, the preferential solvation parameters $\delta x_{1,3}$ of amygdalin in the binary solvent mixtures at the studied temperatures are calculated [70].

According to the literature, positive values of $\delta x_{1,3}$ indicate preferential solvation of amygdalin by ethanol. Conversely, negative values of $\delta x_{1,3}$ indicate preferential solvation of amygdalin by water.

The values of $\delta x_{1,3}$ are presented in Table 5 and the behavior of $\delta x_{1,3}$ is illustrated in Figure 8. Thus, from neat water to $x_{1}=0.45$, the absolute value of $\delta x_{1,3}$ is inferior to 0.01 , indicating insignificant preferential solvation, probably because the values are within the error of the measurement [60]. From this composition to pure ethanol, the values of $\delta x_{1,3}$ are negative and greater than 0.01 . The maximum negative $\delta x_{1,3}$ value is reached in the mixture $x_{1}=0.75$ (Figure 8 ). These results indicate the preferential solvation of amygdalin by water. Because of the availability of two sugar moieties in the molecular structure of amygdalin, this molecule can form hydrogen bonds with proton-acceptor solvents. At the same time, amygdalin can act as a proton-acceptor (base group) molecule due to the free electron pair of the oxygen atom in the $\mathrm{OH}$ group or nitrogen atom of the $\mathrm{C} \equiv \mathrm{N}$ group. Thus, the tendency of amygdalin for water in ethanol-rich mixtures could be explained in the matter of the greater acidic character of water (1.17 for water and 0.86 for ethanol, as stated in the acid scale of Taft and Kamlet [71]) interacting with proton-acceptor groups of amygdalin.

Table 5. The $\delta \mathrm{x}_{1.3}$ values of amygdalin in $\{$ ethanol (1) + water (2)\} mixtures at some temperatures.

\begin{tabular}{|c|c|c|c|c|c|}
\hline \multirow{2}{*}{$x_{1}^{\mathrm{a}}$} & \multicolumn{5}{|c|}{$\delta x_{1,3}$} \\
\hline & 293.15 & 298.15 & 303.15 & 308.15 & 313.15 \\
\hline 0.000 & 0.000 & 0.000 & 0.000 & 0.000 & 0.000 \\
\hline 0.050 & -0.001 & -0.001 & -0.001 & -0.002 & -0.001 \\
\hline 0.100 & -0.001 & -0.002 & -0.002 & -0.002 & -0.002 \\
\hline 0.150 & -0.001 & -0.002 & -0.002 & -0.002 & -0.002 \\
\hline 0.200 & -0.001 & -0.001 & -0.001 & -0.001 & -0.001 \\
\hline 0.250 & 0.000 & 0.000 & 0.000 & 0.000 & 0.000 \\
\hline 0.300 & 0.001 & 0.001 & 0.000 & 0.000 & 0.000 \\
\hline 0.350 & 0.000 & 0.000 & -0.001 & -0.002 & -0.002 \\
\hline 0.400 & -0.002 & -0.003 & -0.004 & -0.005 & -0.005 \\
\hline 0.450 & -0.007 & -0.008 & -0.009 & -0.010 & -0.010 \\
\hline 0.500 & -0.014 & -0.015 & -0.017 & -0.017 & -0.017 \\
\hline 0.550 & -0.023 & -0.024 & -0.026 & -0.026 & -0.026 \\
\hline 0.600 & -0.033 & -0.035 & -0.037 & -0.036 & -0.036 \\
\hline 0.650 & -0.043 & -0.046 & -0.048 & -0.046 & -0.047 \\
\hline 0.700 & -0.051 & -0.054 & -0.056 & -0.054 & -0.056 \\
\hline 0.750 & -0.052 & -0.055 & -0.058 & -0.057 & -0.059 \\
\hline 0.800 & -0.044 & -0.047 & -0.050 & -0.051 & -0.054 \\
\hline 0.850 & -0.030 & -0.033 & -0.035 & -0.037 & -0.039 \\
\hline 0.900 & -0.016 & -0.017 & -0.018 & -0.021 & -0.022 \\
\hline 0.950 & -0.005 & -0.005 & -0.006 & -0.008 & -0.008 \\
\hline 1.000 & 0.000 & 0.000 & 0.000 & 0.000 & 0.000 \\
\hline
\end{tabular}

a $x_{1}$ is the mole fraction of ethanol (1) in the \{ethanol (1) + water (2)\} mixtures free of amygdalin (3). 


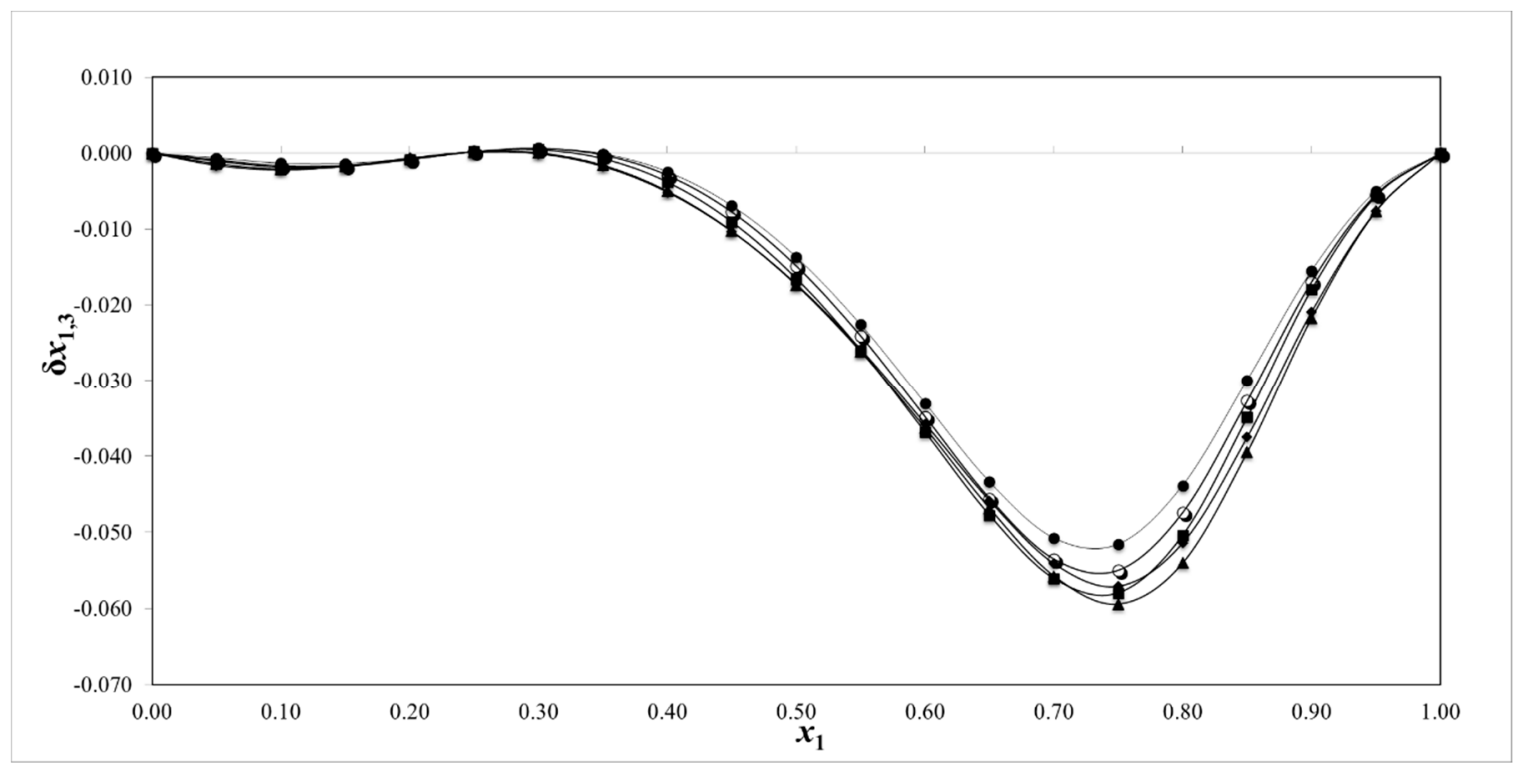

Figure 8. The $\delta x_{1,3}$ values of amygdalin (3) in $\{$ ethanol (1) + water (2)\} mixtures at mixtures •: $293.15 \mathrm{~K}$; ○: $298.15 \mathrm{~K}$; : 303.15 ; $\mathbf{\square}: 308.15 \mathrm{~K}$; and $\mathbf{\Delta}: 313.15 \mathrm{~K}$.

\section{Experimental procedures}

\subsection{Reagents}

Amygdalin (purity 98\%) and HPLC-grade ethanol (purity 99.9\%) were acquired from Sigma-Aldrich (San Luis, WA, USA).

Doubly distilled and deionized water were used in all experiments. All chemicals were used without further purification.

\subsection{Solubility Determination}

The employed techniques to prepare ethanol-water binary solvent mixtures and to measure the solubility of amygdalin in these solvents were used as reported in different studies [72-74]. The solubility of amygdalin in pure and mixed solvents was investigated at different temperatures in the range of $298.15-328.15 \mathrm{~K}$. The gravimetric method was used to measure the composition of the saturated solutions.

The solvent mixtures were prepared by mass using a Sartorius balance (CP225D) with an accuracy of $\pm 0.01 \mathrm{mg}$. An excess of amygdalin powder was added to the liquid phase, and the saturated solutions were brought into a twofold jacketed reactor (Polystat Huber CC2) at $\mathrm{T} \pm 0.1 \mathrm{~K}$. The solutions are magnetically stirred at the desired temperature for at least $72 \mathrm{~h}$ to ensure the saturation equilibrium. Thereafter, they were allowed to settle for $2 \mathrm{~h}$ before sampling.

The supernatant solutions were withdrawn, filtered through a $0.45-\mu \mathrm{m}$ syringe filter, and then dried in a vacuum oven at $328.15 \mathrm{~K}$. The mass of the dried samples was periodically measured using an analytical balance until stability. All determinations were performed three times to check reproducibility, and then an average value was taken to determine the amygdalin solubility in all systems at each condition. The solubility of amygdalin was calculated by molar fraction $\left(x_{A}\right)$ in pure and different binary ethanol-water mixtures using the Equations (1) and (2), respectively.

\section{Conclusions}

The solubilities of amygdalin in \{ethanol (1) + water (2)\} mixtures were determined at different temperatures. The maximum solubility was obtained in 0.4-mole fraction of ethanol at $328.15 \mathrm{~K}$ and the lowest one in pure ethanol at $293.15 \mathrm{~K}$. The amygdalin solubility was calculated using the 
van't Hoff, Jouyban-Acree-van't Hoff, and Buchowski-Ksiazczak models, the data obtained using the Jouyban-Acree-van't Hoff model showing important deviations with respect to experimental solubility; however, the van't Hoff and Buchowski-Ksiazczak models showed a good correlation with the experimental data. As for solution thermodynamics, an endothermic process was observed, with a pronounced enthalpic contribution, but with entropic conduction.

The IKBI approach demonstrated that amygdalin is preferentially solvated by water in ethanol-rich mixtures, which is consistent with the decrease in amygdalin solubility by the addition of ethanol. Whereas, in water-rich mixtures $\left(0<x_{1}<0.45\right)$, the solvent that will solvate the amygdalin molecule was not well defined.

In general terms, the data presented in this research expand the physicochemical information of amygdalin in binary aqueous-cosolvent mixtures, which are very useful, both for the pharmaceutical industry and for research processes related to this drug.

Author Contributions: Formal analysis, M.A.; Funding acquisition, K.G.; Methodology, C.A., K.G. and L.K.; Supervision, D.R.D.; Validation, A.Z.A.-K.; Writing-review \& editing, A.A. and K.G. All authors have read and agreed to the published version of the manuscript.

Funding: This research was funded by the Deanship of Scientific Research at Princess Nourah bint Abdulrahman University through the Fast-track Research Funding Program.

Conflicts of Interest: The authors declare that they have no known competing financial interests or personal relationships that could have appeared to influence the work reported in this paper.

\section{References}

1. Jaswal, V.; Palanivelu, J.; Ramalingam, C. Effects of the Gut microbiota on Amygdalin and its use as an anti-cancer therapy: Substantial review on the key components involved in altering dose efficacy and toxicity. Biochem. Biophys. Rep. 2018, 14, 125-132. [CrossRef]

2. Guo, J.; Wu, W.; Sheng, M.; Yang, S.; Tan, J. Amygdalin inhibits renal fibrosis in chronic kidney disease. Mol. Med. Rep. 2013, 7, 1453-1457. [CrossRef]

3. Carter, J.H.; McLafferty, M.A.; Goldman, P. Role of the gastrointestinal microflora in Amygdalin (laetrile)-induced cyanide toxicity. Biochem. Pharmacol. 1980, 29, 301-304. [CrossRef]

4. Li, Y.; Li, Q.; Liu, R.; Shen, X. Chinese Medicine Amygdalin and $\beta$-Glucosidase Combined with Antibody Enzymatic Prodrug System as A Feasible Antitumor Therapy. Chin. J. Integr. Med. 2015, 24, 237-240. [CrossRef]

5. Moon, J.Y.; Kim, S.W.; Yun, G.M.; Lee, H.S.; Kim, Y.D.; Jeong, G.J.; Ullah, I.; Rho, G.J.; Jeon, B.G. Inhibition of cell growth and down-regulation of telomerase activity by Amygdalin in human cancer cell lines. Anim. Cells Syst. 2015, 19, 295-304. [CrossRef]

6. Song, Z.; Xu, X. Advanced research on anti-tumor effects of Amygdalin. J. Cancer Res. Ther. 2014, 10, 3.

7. Zhang, X.; Hu, J.; Zhuo, Y.; Cui, L.; Li, C.; Cui, N.; Zhang, S. Amygdalin improves microcirculatory disturbance and attenuates pancreatic fibrosis by regulating the expression of endothelin- 1 and calcitonin gene-related peptide in rats. J. Chin. Med. Assoc. 2018, 81, 437-443. [CrossRef]

8. Hwang, H.J.; Lee, H.J.; Kim, C.J.; Shim, I.; Hahm, D.H. Inhibitory effect of Amygdalin on lipopolysaccharide-inducible TNF-alpha and IL-1beta mRNA expression and carrageenan-induced rat arthritis. J. Microbiol. Biotechnol. 2008, 18, 1641-1647.

9. Zhu, Y.P.; Su, Z.W.; Li, C.H. Analgesic effect and no physical dependence of Amygdalin. China J. Chin. Mater. Med. 1994, 19, 105-107.

10. Jiagang, D.; Li, C.; Wang, H.; Hao, E.; Du, Z.; Bao, C.; Lv, J.; Wang, Y. Amygdalin mediates relieved atherosclerosis in apolipoprotein $\mathrm{E}$ deficient mice through the induction of regulatory $\mathrm{T}$ cells. Biochem. Biophys. Res. Commun. 2011, 411, 523-529. [CrossRef] [PubMed]

11. Zhao, F.; Yang, Z. Amygdalin attenuates atherosclerosis progress through inhibiting of toll-like receptors expression and activity. J. Anim. Vet. Adv. 2012, 11, 1613-1621. [CrossRef]

12. Wang, Z.; Fang, K.; Wang, G.; Guan, X.; Pang, Z.; Guo, Y.; Yuan, Y.; Ran, N.; Liu, Y.; Wang, F. Protective effect of Amygdalin on epithelial-mesenchymal transformation in experimental chronic obstructive pulmonary disease mice. Phytother. Res. 2019, 33, 808-817. [CrossRef] [PubMed] 
13. He, X.Y.; Wu, L.J.; Wang, W.X.; Xie, P.J.; Chen, Y.H.; Wang, F. Amygdalin-A pharmacological and toxicological review. J. Ethnopharmacol. 2020, 112717. [CrossRef]

14. Nabavizadeh, F.; Alizadeh, A.M.; Sadroleslami, Z.; Adeli, S. Gastroprotective effects of Amygdalin on experimental gastric ulcer: Role of NO and TNF- $\alpha$. J. Med. Plant Res. 2011, 5, 3122-3127.

15. Lee, H.M.; Moon, A. Amygdalin regulates apoptosis and adhesion in Hs578T triple-negative breast cancer cells. Biomol. Ther. 2016, 24, 62. [CrossRef] [PubMed]

16. Haisman, D.R.; Knight, D.J. The enzymic hydrolysis of Amygdalin. Biochem. J. 1967, 103, 528-534. [CrossRef]

17. Bolarinwa, I.F.; Orfila, C.; Morgan, M.R. Amygdalin content of seeds, kernels and food products commercially-available in the UK. Food Chem. 2014, 52, 133-139. [CrossRef]

18. Krieble, V.K. The amygdalins and their inter-reactions with emulsin. J. Am. Chem. Soc. 1912, 34, 716-735. [CrossRef]

19. Boháčová, I.; Procházková, S.; Halko, R. Separation and determination of Amygdalin and unnatural neoAmygdalin in natural food supplements by HPLC-DAD. Food Addit. Contam. Part A 2019, 36, 1445-1452. [CrossRef]

20. Thapa, R.K.; Choi, H.G.; Kim, J.O.; Yong, C.S. Analysis and optimization of drug solubility to improve pharmacokinetics. J. Pharm. Investig. 2017, 47, 95-110. [CrossRef]

21. Pacheco, D.P.; Martínez, F. Thermodynamic analysis of the solubility of naproxen in ethanol + water cosolvent mixtures. Phys. Chem. Liq. 2007, 45, 581-595. [CrossRef]

22. Di, L.; Fish, P.V.; Mano, T. Bridging solubility between drug discovery and development. Drug Discov. Today 2012, 17, 486-495. [CrossRef]

23. Sun, H.; Li, M.; Jia, J.; Tang, F.; Duan, E. Measurement and correlation of the solubility of 2, 6-diaminohexanoic acid hydrochloride in aqueous methanol and aqueous ethanol mixtures. J. Chem. Eng. Data. 2012, 57, 1463-1467. [CrossRef]

24. Delgado, D.R.; Martínez, F. Solubility and solution thermodynamics of sulfamerazine and sulfamethazine in some ethanol+ water mixtures. Fluid Phase Equilibria 2013, 360, 88-96. [CrossRef]

25. Pobudkowska, A.; Domańska, U.; Jurkowska, B.A.; Dymczuk, K. Solubility of pharmaceuticals in water and alcohols. Fluid Phase Equilibria 2015, 392, 56-64. [CrossRef]

26. Allen, L.; Ansel, H.C. Ansel's Pharmaceutical Dosage Forms and Drug Delivery Systems; Lippincott Williams \& Wilkins: Philadelphia, PA, USA, 2013.

27. Wijesekera, R.O.B. The Medicinal Plant Industry; Routledge: Abingdon-on-Thames, UK, 2017.

28. Marcus, Y. Preferential solvation in mixed solvents. In Fluctuation Theory of Solutions: Applications in Chemistry, Chemical Engineering, and Biophysics; CRC Press: Boca Raton, FL, USA, 2013; pp. 65-92.

29. Marcus, Y. Preferential solvation of drugs in binary solvent mixtures. Pharm. Anal. Acta 2017, 8, 537. [CrossRef]

30. Yalkowsky, S.H. Solubility and Solubilization in Aqueous Media; American Chemical Society: New York, USA, 1999.

31. Williams, R.O., III; Watts, A.B.; Miller, D.A. Formulating Poorly Water Soluble Drugs; American Association of Pharmaceutical Scientists: Austin, TX, USA, 2016.

32. Delgado, D.R.; Rodríguez, G.A.; Martínez, F. Thermodynamic study of the solubility of sulfapyridine in some ethanol + water mixtures. J. Mol. Liq. 2013, 177, 156-161. [CrossRef]

33. Muñoz, M.d.; Delgado, D.R.; Peña, M.Á.; Jouyban, A.; Martínez, F. Solubility and preferential solvation of sulfadiazine, sulfamerazine and sulfamethazine in propylene glycol + water mixtures at $298.15 \mathrm{~K}$. J. Mol. Liq. 2015, 204, 132-136. [CrossRef]

34. Barton, A. CRC Handbook of Solubility Parameters and Other Cohesion Parameters, 2nd ed.; CRC Press: New York, NY, USA, 1991.

35. Delgado, D.R.; Mogollon-Waltero, E.M.; Ortiz, C.P.; Peña, M.; Almanza, O.A.; Martínez, F.; Jouyban, A. Enthalpy-entropy compensation analysis of the triclocarban dissolution process in some $\{1,4$-dioxane (1) + water (2)\} mixtures. J. Mol. Liq. 2018, 271, 522-529. [CrossRef]

36. Hildebtand, J.H.; Prausnitz, J.M.; Scott, R.L. Regular and Related Solutions: The Solubility of Gases, Liquids, and Solids; Van Nostrand Reinhold Company: New Tork, NY, USA, 1970.

37. Grant, D.J.W.; Mehdizadeh, M.; Chow, A.H.L.; Fairbrother, J.E. Non-linear van't Hoff solubility-temperature plots and their pharmaceutical interpretation. Int. J. Pharm. 1984, 18, 25-38. [CrossRef]

38. Jouyban, A.; Acree, W.E. Mathematical derivation of the Jouyban-Acree model to represent solute solubility data in mixed solvents at various temperatures. J. Mol. Liq. 2018, 256, 541-547. [CrossRef]

39. Ruidiaz, M.; Delgado, D.R.; Martínez, F. Correlating the solubility of indomethacin in 1,4-dioxane + water mixtures by means of the Jouyban-Acree model. Rev. Colomb. Cienc. Quimico Farm. 2010, 39, 211-226. 
40. Acree, W.; Jouyban, A.; Acree, W.E. In silico prediction of drug solubility in water-ethanol mixtures using Jouyban-Acree model. J. Pharm Pharm. Sci. 2006, 9, 262-269.

41. Nieto, A.M.R.; Cerquera, N.E.; Delgado, D.R. Measurement and correlation of solubility of ethylparaben in pure and binary solvents and thermodynamic properties of solution. Rev. Colomb. Cienc. Químico Farm. 2019, 48, 332-347. [CrossRef]

42. Ksiąẑczak, A.; Kosinski, J.J. Vapour pressure of binary, three-phase (S-L-V) systems and solubility. Fluid Phase Equilibria 1988, 44, 211-236. [CrossRef]

43. Ksiazczak, A.; Moorthi, K.; Nagata, I. Solid-solid transition and solubility of even n-alkanes. Fluid Phase Equilibria 1994, 95, 15-29. [CrossRef]

44. Krajangsod, S.; Chotikamas, S.; Tawai, A.; Sriariyanun, M. Measurement and thermodynamic modelling of erythritol solubility in aqueous solvents. Orient. J. Chem. 2018, 34, 265-275. [CrossRef]

45. Blanco-Márquez, J.H.; Quigua-Medina, Y.A.; García-Murillo, J.D.; Castro-Camacho, J.K.; Ortiz, C.P.; Cerquera, N.E.; Delgado, D.R. Thermodynamic analysis and applications of the Abraham solvation parameter model in the study of the solubility of some sulfonamides. Rev. Colomb. Cienc. Quimico-Farm. 2020, 49, 234-255.

46. Khoubnasabjafari, M.; Delgado, D.R.; Martinez, F.; Jouyban, A.; Acree, W.E. Predicting the solubility, thermodynamic properties and preferential solvation of sulphamethazine in \{acetonitrile + water\} mixtures using a minimum number of experimental data points. Phys. Chem. Liq. 2020. [CrossRef]

47. Krug, R.R.; Hunter, W.G.; Grieger, R.A. Enthalpy-entropy compensation. 1. Some fundamental statistical problems associated with the analysis of van't Hoff and arrhenius data. J. Phys. Chem. 1976, 80, 2335-2341. [CrossRef]

48. Krug, R.R.; Hunter, W.G.; Grieger, R.A. Enthalpy-entropy compensation. 2. Separation of the chemical from the statistical effect. J. Phys. Chem. 1976, 80, 2341-2351. [CrossRef]

49. Delgado, D.R.; Jouyban, A.; Martínez, F. Solubility and preferential solvation of meloxicam in methanol + water mixtures at 298.15 K. J. Mol. Liq. 2014, 197, 368-373. [CrossRef]

50. Blanco-Márquez, J.H.; Ortiz, C.P.; Cerquera, N.E.; Martínez, F.; Jouyban, A.; Delgado, D.R. Thermodynamic analysis of the solubility and preferential solvation of sulfamerazine in (acetonitrile + water) cosolvent mixtures at different temperatures. J. Mol. Liq. 2019, 293, 111507. [CrossRef]

51. Valvani, S.C.; Yalkowsky, S.H.; Amidon, G.L. Solubility of nonelectrolytes in polar solvents. VI. Refinements in molecular surface area computations. J. Phys. Chem. 1976, 80, 829-835. [CrossRef]

52. Machatha, S.G.; Bustamante, P.; Yalkowsky, S.H. Deviation from linearity of drug solubility in ethanol/water mixtures. Int. J. Pharm. 2004, 283, 83-88. [CrossRef] [PubMed]

53. Volkova, T.V.; Levshin, I.B.; Perlovich, G.L. New antifungal compound: Solubility thermodynamics and partitioning processes in biologically relevant solvents. J. Mol. Liq. 2020, 310, 113148. [CrossRef]

54. Perlovich, G.L.; Strakhova, N.N.; Kazachenko, V.P.; Volkova, T.V.; Tkachev, V.V.; Schaper, K.J.; Raevsky, O.A. Sulfonamides as a subject to study molecular interactions in crystals and solutions: Sublimation, solubility, solvation, distribution and crystal structure. Int. J. Pharm. 2008, 349, 300-313. [CrossRef]

55. Bustamante, P.; Escalera, B. Enthalpy and Entropy Contributions to the Solubility of Sulphamethoxypyridazine in Solvent Mixtures Showing Two Solubility Maxima. J. Pharm. Pharmacol. 1995, 47, 550-555. [CrossRef]

56. Bustamante, E.P.; Ochoa, R.; Reillo, A.; Escalera, J.-B. Chameleonic Effect of Sulfanilamide and Sulfamethazine in Solvent Mixtures. Solubility Curves with Two Maxima. Chem. Pharm. Bull. 1994, 42, 1129-1133. [CrossRef]

57. Ben-Naim, A. Theory of preferential solvation of nonelectrolytes. Cell Biophys. 1988, 12, 255-269. [CrossRef]

58. Ben-Naim, A. Theoretical aspects of self-assembly of proteins: A Kirkwood-Buff-theory approach. J. Chem. Phys. 2013, 138, 06B609_1. [CrossRef] [PubMed]

59. Ben-Naim, A.; Navarro, A.M.; Leal, J.M. A Kirkwood-Buff analysis of local properties of solutions. Phys. Chem. Chem. Phys. 2008, 10, 2451-2460. [CrossRef] [PubMed]

60. Marcus, Y. Solvent Mixtures: Properties and Selective Solvation; CRC Press: New York, NY, USA, 2002.

61. Marcus, Y. On the preferential solvation of drugs and PAHs in binary solvent mixtures. J. Mol. Liq. 2008, 140, 61-67. [CrossRef]

62. Delgado, D.R.; Vargas, E.F.; Martínez, F. Preferential solvation of xylitol in ethanol + water co-solvent mixtures according to the IKBI and QLQC methods. Rev. Colomb. Quim. 2013, 42, 125-133.

63. Marcus, Y. Preferential solvation in mixed solvents. 16. Mixtures of N,N-dimethylformamide or propylene carbonate with organic solvents. J. Chem. Thermodyn. 2020, 140, 105903. [CrossRef] 
64. Delgado, D.R.; Peña, M.A.; Martínez, F. Preferential solvation of acetaminophen in ethanol + water solvent mixtures according to the inverse Kirkwood-Buff integrals method. Rev. Colomb Cienc. Químico Farm. 2013, 42, 298-314.

65. Marcus, Y. Preferential solvation in mixed solvents. 15. Mixtures of acetonitrile with organic solvents. J. Chem. Thermodyn. 2019, 135, 55-59. [CrossRef]

66. Castro, J.J.S.; Ortiz, C.P.; Rodríguez-Rubiano, J.D.; Rodríguez-Rodríguez, G.A.; Delgado, D.R. Preferential solvation of tricin in $\{$ ethanol (1) + water (2)\} mixtures at several temperatures. Rev. Colomb. Cienc. Químico Farm. 2018, 47, 135-148. [CrossRef]

67. Marcus, Y. Preferential solvation. Part 3.-Binary solvent mixtures. J. Chem. Soc. Faraday Trans. 1 Phys. Chem. Condens. Phases. 1989, 85, 381-388. [CrossRef]

68. Marcus, Y. The Properties of Solvents; John Wiley \& Sons Ltd.: New York, NY, USA, 1999.

69. Jiménez, J.; Manrique, J.; Martínez, F. Effect of temperature on some volumetric properties for ethanol + water mixtures. Rev. Colomb. Cienc. Químico Farm. 2004, 33, 145-155.

70. Aldana, G.A.d.A.; Rubio, D.I.C.; Rodríguez, G.A.R.; Lozano, A.C.; Mehrdad, A.; Delgado, D.R.; Carmona, N.A.P. Solution thermodynamics and preferential solvation of 3-chloro-N-phenyl-phthalimide in acetone + methanol mixtures. Rev. Colomb. Cienc. Químico Farm. 2016, 45, 256. [CrossRef]

71. Taft, R.W.; Kamlet, M.J. The Solvatochromic Comparison Method. 2. The $\alpha$-Scale of Solvent Hydrogen-Bond Donor (HBD) Acidities. J. Am. Chem. Soc. 1976, 98, 2886-2894. [CrossRef]

72. Noubigh, A. Stearic acid solubility in mixed solvents of (water + ethanol) and (ethanol + ethyl acetate): Experimental data and comparison among different thermodynamic models. J. Mol. Liq. 2019, 296, 112101. [CrossRef]

73. Noubigh, A.; Aydi, A.; Abderrabba, M. Experimental measurement and correlation of solubility data and thermodynamic properties of protocatechuic acid in four organic solvents. J. Chem. Eng. Data 2017, 60, 514-518. [CrossRef]

74. Noubigh, A.; Akremi, A. Solution thermodynamics of trans-Cinnamic acid in (methanol + water) and (ethanol + water) mixtures at different temperatures. J. Mol. Liq. 2019, 274, 752-758. [CrossRef]

Publisher's Note: MDPI stays neutral with regard to jurisdictional claims in published maps and institutional affiliations.

(C) 2020 by the authors. Licensee MDPI, Basel, Switzerland. This article is an open access article distributed under the terms and conditions of the Creative Commons Attribution (CC BY) license (http://creativecommons.org/licenses/by/4.0/). 